\title{
THE EFFECT OF THE INJECTION OF HISTAMINE INTO THE BRACHIAL ARTERY ON THE PERMEABILITY OF THE CAPILLARIES OF THE FOREARM AND HAND ${ }^{1}$
}

\author{
By EUGENE A. STEAD, JR., AND JAMES V. WARREN \\ (From the Medical Service of Grady Hospital and the Department of Medicine, Emory University \\ School of Medicine, Atlanta)
}

(Received for publication October 13, 1943)

The capillaries of the human forearm and hand are relatively impermeable to protein, and the protein concentration of normal capillary filtrate in these parts is not more than 5 per cent of the protein concentration of the plasma $(1,2)$. Injury makes the capillaries more permeable. In patients with peritonitis, burns, and certain forms of trauma, the capillaries in the involved areas leak protein profusely. If enough capillaries are involved, the plasma volume is decreased and shock develops. A study of the reaction of the capillaries of the forearm to the intra-arterial injection of histamine, which might be expected to make the capillaries more permeable, is, therefore, of both theoretical and practical importance.

Landis, Jonas, Angevine, and Erb (1) have described a method for determining the passage of fluid and protein through the capillary wall during venous congestion. They assumed that the loss of water from the blood would produce a proportionate increase in the packed red cell volume and in the serum protein concentration of the blood draining from the part. They made allowance for the fact that the cell volume is measured in volumes per cent of the whole blood, while the proteins are measured in the percentage of plasma. A rise in hematocrit reading without a corresponding rise in the protein concentration was interpreted as indicating that protein was escaping from the capillaries. This method was used in our laboratory to determine whether the injection of histamine into the brachial artery altered the permeability of the capillaries of the hand and forearm to protein.

1 The work described in this paper was done under a contract, recommended by the Committee on Medical Research, between the Office of Scientific Research and Development and the Emory University School of Medicine.

\section{METHOD}

Normal healthy males served as subjects. They rested in the recumbent position for at least $\mathbf{3 0}$ minutes before the experiment was begun. The hematocrit reading was measured on heparinized blood. The hemoglobin concentration was determined with a photoelectric colorimeter. The serum protein was calculated from the specific gravity by the method of Kagan (3).

\section{RESULTS}

Fifteen hundredths mgm. of histamine was injected into the right brachial artery of 2 subjects. A needle was left in place in the right antecubital vein before and for several minutes after the injection of histamine, and samples of blood were taken throughout this period.

The subjects complained of pain in the fingers, the skin of the hand and forearm became bright red and the part throbbed. In a few minutes, the finger and hand felt stiff and swollen. The reaction was confined to the extremity. There were no systemic effects. These observations were similar to those previously recorded by other workers (4). The hematocrit reading and the hemoglobin concentration of the blood draining from the forearm increased, but the protein concentration showed little change (Table I). This demonstrated that the capillaries had become permeable to protein and that plasma was passing into the tissues.

Four successful experiments were carried out, using a different technique. A blood pressure cuff was placed on the arm above the elbow. A control sample of blood was drawn without stasis. From 0.1 to $0.15 \mathrm{mgm}$. of histamine was injected intra-arterially. The pressure in the cuff was raised to the level of the diastolic blood pressure for a period of time lasting from 15 to 60 seconds. The cuff was then inflated to 200 $\mathrm{mm}$. $\mathrm{Hg}$. After 5 minutes, the blood in the forearm was removed by inserting a needle into 
TABLE I

The effect of the injection of $0.15 \mathrm{mgm}$. of histamine into the brachial artery on the blood draining from the forearm and hand

\begin{tabular}{|c|c|c|c|c|}
\hline $\begin{array}{l}\text { Sub- } \\
\text { ject }\end{array}$ & $\begin{array}{l}\text { Relation to injection } \\
\text { of histamine }\end{array}$ & $\begin{array}{l}\text { Hemo- } \\
\text { globin }\end{array}$ & $\begin{array}{c}\text { Hema- } \\
\text { tocrit } \\
\text { reading }\end{array}$ & $\begin{array}{l}\text { Serum } \\
\text { protein }\end{array}$ \\
\hline J. W. & $\begin{array}{l}\text { Before histamine } \\
1 \frac{1}{2} \text { minutes after histamine } \\
1 \frac{3}{4} \text { minutes after histamine } \\
2 \frac{3}{4} \text { minutes after histamine } \\
3 \frac{1}{2} \text { minutes after histamine } \\
4 \frac{1}{4} \text { minutes after histamine } \\
5 \text { minutes after histamine }\end{array}$ & $\begin{array}{c}\text { grams } \\
\text { per } \\
100 \text { cc. } \\
13.9 \\
14.6 \\
15.0 \\
14.9 \\
14.6 \\
14.4 \\
14.5\end{array}$ & 43.5 & $\begin{array}{c}\text { grams } \\
\text { per } \\
100 \text { cc. } \\
5.8 \\
6.0 \\
5.8 \\
5.8 \\
5.8 \\
5.8 \\
5.8\end{array}$ \\
\hline E. S. & $\begin{array}{l}\text { Before histamine } \\
1 \frac{1}{2} \text { minutes after histamine } \\
2 \frac{1}{2} \text { minutes after histamine } \\
5 \frac{1}{4} \text { minutes after histamine } \\
6 \text { minutes after histamine }\end{array}$ & $\begin{array}{l}14.2 \\
15.6 \\
15.4 \\
14.9 \\
14.8\end{array}$ & $\begin{array}{r}43.8 \\
47.0\end{array}$ & $\begin{array}{l}6.2 \\
6.3 \\
6.2 \\
6.1 \\
6.1\end{array}$ \\
\hline
\end{tabular}

the antecubital vein and elevating the forearm and hand. The last portion of the blood was obtained by milking the tissues of the forearm towards the needle. By this time, from 10 to 13 minutes had elapsed since the arterial inflow was occluded. The data on the specimen of blood taken before the injection of the histamine and on the last portion of blood obtained from the forearm are given in Table II. The blood from the small vessels showed a striking rise in hematocrit reading and only a slight increase in protein concentration. Either the injection of histamine or the period of arterial occlusion or both had altered capillary permeability.

A similar type of experiment, omitting the injection of histamine and prolonging the period of arterial occlusion, was performed in 4 subjects. After the control sample was obtained, the cuff on the arm was inflated to diastolic pressure for a period of time varying from 15 to 30 seconds. The pressure was then raised to $200 \mathrm{~mm}$. $\mathrm{Hg}$. for from 5 to 10 minutes. The blood in the forearm was then collected by inserting a needle into the antecubital vein and elevating the arm. The last sample of blood was obtained from 9 to 15 minutes after the arterial occlusion. The data are given in Table III. The hematocrit reading and protein concentration both tended to increase and the marked discrepancy between the increase in cell volume and the increase in protein concentration, which occurred in the histamine experiments, was not present. This indicates that the majority of the changes observed in the histamine experiments resulted from the effect of histamine on the capillaries and that the accompanying ischemia had much less effect on the permeability of the capillaries.

\section{COMMENT}

Histamine produces a wheal when it is pricked into the skin. This wheal contains fluid which has a high concentration of protein (5). The experiments reported here demonstrate that histamine injected intra-arterially produces an increase in permeability in the area supplied by the artery. With the size dose employed, the effect was confined to the area supplied by the brachial artery. The same quantity of histamine injected intravenously produced no change in the hematocrit reading or protein content of the blood. The arterial blood entering the forearm was normal in composition. The venous blood leaving the forearm showed hemoconcentration because of the leakage of plasma into the tissues.

None of the patients that we have observed in shock have shown a histamine-like reaction in uninjured tissue. The erythema of the skin and the rapid swelling of an uninjured part do not

TABLE II

Effect of the intrabrachial injection of histamine on blood trapped in the forearm by a tourniquet

The venous pressure was raised before the arterial tourniquet was applied.

\begin{tabular}{|c|c|c|c|c|}
\hline$\underset{\text { ject }}{\text { Sub- }}$ & $\begin{array}{c}\text { Relation to injection } \\
\text { of histamine }\end{array}$ & $\begin{array}{c}\text { Hemo- } \\
\text { globin }\end{array}$ & $\mid \begin{array}{c}\text { Hema- } \\
\text { tocrit } \\
\text { reading }\end{array}$ & $\begin{array}{l}\text { Serum } \\
\text { protein }\end{array}$ \\
\hline J. P. & $\begin{array}{l}\text { Before histamine } \\
10 \text { minutes after } 0.15 \mathrm{mgm} . \\
\text { histamine }\end{array}$ & $\begin{array}{c}\text { grams } \\
\text { per } \\
100 \text { cc. } \\
14.0 \\
16.4\end{array}$ & $\begin{array}{r}41.9 \\
49.7\end{array}$ & $\begin{array}{c}\text { grams } \\
\text { per } \\
100 \text { cc. } \\
6.0 \\
6.5\end{array}$ \\
\hline T. L. & $\begin{array}{l}\text { Before histamine } \\
10 \text { minutes after } 0.10 \mathrm{mgm} . \\
\text { histamine }\end{array}$ & $\begin{array}{l}14.7 \\
17.0\end{array}$ & $\begin{array}{l}48.5 \\
55.4\end{array}$ & $\begin{array}{l}6.0 \\
6.4\end{array}$ \\
\hline J. W. & $\begin{array}{l}\text { Before histamine } \\
10 \text { minutes af ter } 0.15 \mathrm{mgm} . \\
\text { histamine }\end{array}$ & $\begin{array}{l}13.9 \\
16.5\end{array}$ & $\begin{array}{l}41.6 \\
49.1\end{array}$ & $\begin{array}{l}5.7 \\
6.0\end{array}$ \\
\hline A. G. & $\begin{array}{l}\text { Before histamine } \\
13 \text { minutes after } 0.15 \mathrm{mgm} . \\
\text { histamine }\end{array}$ & $\begin{array}{l}17.0 \\
21.1\end{array}$ & $\begin{array}{l}48.5 \\
60.1\end{array}$ & $\begin{array}{l}6.0 \\
6.3\end{array}$ \\
\hline
\end{tabular}


TABLE III

Effect of ischemia on the blood trapped in the forearm by an arterial tourniquet

The venous pressure was raised before the arterial tourniquet was applied.

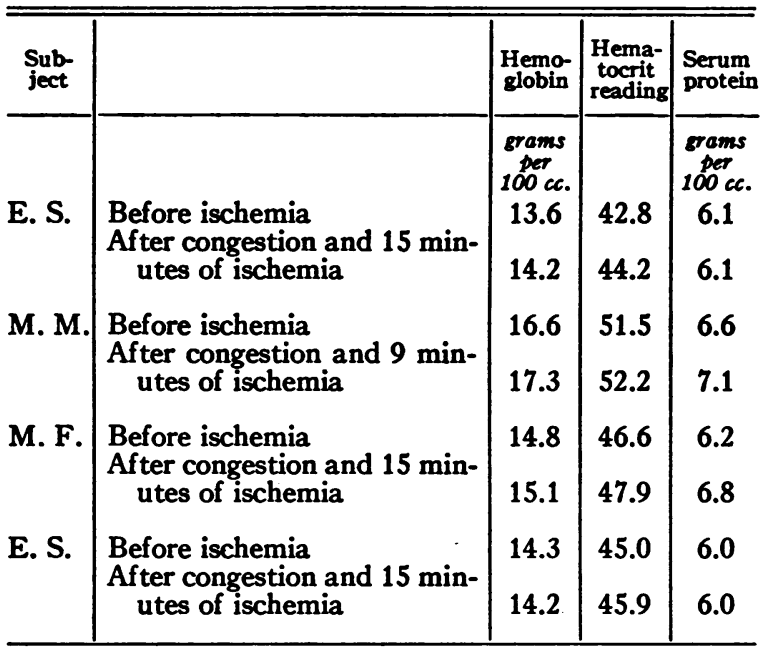

occur in patients with circulatory failure from burns, peritonitis, trauma, or infection. In patients dying of acute infectious diseases, the hematocrit reading and protein concentration of the arterial blood and the venous blood from the antecubital vein were compared (6). No evidence was obtained that protein was leaking into the tissues as the result of capillary injury. Patients with anaphylactic reactions have not been studied.

\section{SUMMARY AND CONCLUSIONS}

1. Histamine injected intra-arterially increases the permeability of the capillaries supplied by the artery. The rapid loss of protein from the plasma can be detected by comparing the blood draining from the part before and after the injection. The hematocrit reading and hemoglobin concentration increased markedly while the protein concentration rose only slightly.

2. A reaction similar to that produced by histamine is not seen in uninjured tissue in the usual types of shock.

\section{BIBLIOGRAPHY}

1. Landis, E. M., Jonas, L., Angevine, M., and Erb, W., The passage of fluid and protein through the human capillary wall during venous congestion. J. Clin. Invest., 1932, 11, 717.

2. Warren, J. V., and Stead, E. A., Jr., The protein content of capillary filtrate in normal subjects and in patients with cardiac failure, anoxemia and fever (In press).

3. Kagan, B. M., A simple method for the estimation of total protein content of plasma and serum: I. A falling drop method for the determination of specific gravity. J. Clin. Invest., 1938, 17, 369.

4. Allen, E. V., and Crisler, G. R., The result of intraarterial injection of vasodilating drugs on the circulation: Observations on vasomotor gradient. J. Clin. Invest., 1937, 16, 649.

5. Lewis, T., The Blood Vessels of the Human Skin and their Responses. Shaw \& Sons, London, 1927.

6. Stead, E. A., Jr., and Ebert, R. V., Unpublished observations. 